\title{
Cells snag top modelling job
}

\section{Heart disorder joins growing list of conditions getting the ‘disease in a dish' treatment.}

\section{BY EWEN CALLAWAY}

$\mathrm{W}$ hen an unconscious 28-year-old woman with a rare heart disorder was rushed to hospital, surgeons saved her life by implanting a defibrillator. In time, a sample of her cells, alive and beating in a dish, could help to save other lives.

This is the hope for patient-specific models of disease, which can be created by reprogramming the patient's cells in the lab into an undifferentiated stem-cell state and then converting them into the specialized cell types affected by the condition. A handful of such models have been created so far for diseases ranging from diabetes to rare neurodegenerative diseases (see 'Dishy models'), with many more expected soon. Pharmaceutical companies are beginning to use these cells to identify effective drug treatments and to predict side effects that may only appear in a small subset of patients.

"The patient's cells act exactly as the patient was acting when admitted to the hospital," says Lior Gepstein, a stem-cell biologist at the Technion Israel Institute of Technology in Haifa, Israel. His team created induced pluripotent stem (iPS) cells from skin cells donated by the young woman, who suffers from a genetic form of long QT syndrome. They then reprogrammed the cells into heartmuscle cells called myocardiocytes, which can be used to study the disease. Their work was published in Nature ${ }^{1}$ on 16 January.

Long QT syndrome - which gets its name from a telltale anomaly in a patient's electrocardiogram - is caused by delayed electrical recharging in heart-muscle cells. The condition typically stems from inherited mutations in molecular channels that pump ions in and out of cells. People with long QT often die suddenly from arrhythmias, a kind of irregular heartbeat,

\section{DISHY MODELS}

Induced pluripotent stem cells are being used to mimic a growing number of diseases.

\begin{tabular}{l|l|}
\hline $\begin{array}{l}\text { Condition } \\
\text { Amyotrophic lateral } \\
\text { sclerosis }\end{array}$ & $\begin{array}{l}\text { Cells of interest } \\
\text { Motor neurons }\end{array}$ \\
$\begin{array}{l}\text { Spinal muscular } \\
\text { atrophy }\end{array}$ & Motor neurons $^{4}$ \\
\hline $\begin{array}{l}\text { Familial } \\
\text { dysautonomia }\end{array}$ & Neural crest precursors \\
\hline $\begin{array}{l}\text { Long QT } \\
\text { Fanconi anaemia }\end{array}$ & $\begin{array}{l}\text { Myocardiocytes } \\
\text { Haematopoetic progenitors }\end{array}$ \\
\hline Rett syndrome & Neural precursors, neurons \\
\hline
\end{tabular}

in their 20s and 30s. No good animal models of the condition exist, says Gepstein, because rodent hearts beat many times faster than the human heart and use different ion channels.

Heart-muscle cells created from the patient's iPS cells, however, recreated several aspects of her disease in a Petri dish. The cells didn't recharge as quickly as heart-muscle cells made from 'healthy' iPS cells, for example. An earlier patient-specific model of a different form of long QT syndrome found similar results ${ }^{2}$. Both the 'healthy' and the long QT patient-derived heart-muscle cells formed cell sheets in the Petri dish that developed a rudimentary 'heart beat'. But the patient's cells pulsed irregularly. "The normal cells of a healthy individual went boomboom-boom; of the long QT patient they went boom-boom-boomboomboomboom," Gepstein says, doubling his tempo.

Three medicines that help heart cells recharge by targeting different kinds of ion channels all prevented arrhythmias in the diseased cells, proving the model's potential for drug screening. Moreover, the long QT patient's cells beat more irregularly when Gepstein's team treated them with a gastric-acting drug, cisapride, which was pulled from the market in 2000 because it caused lethal arrhythmia in some patients.

Predicting such side effects may be the first application for cells from long QT patients, says Gepstein. But he thinks that the eventual goal of patient-specific disease models should be personalized medicine. Clive Svendsen, director of the Cedars-Sinai Regenerative Medicine Institute in Los Angeles, agrees: "You could prescribe the best drug for a patient without rotating through different drugs and without the danger of multiple side effects."

Christine Mummery, a stem-cell biologist at the University of Leiden in the Netherlands, disagrees, saying that making personalized disease cells is too time-consuming and expensive to treat individual patients. But testing drugs against disease cells from numerous patients and comparing the cells' genetics with their responses could reveal markers that could guide treatment more generally, she says.

First, though, scientists need to overcome a shortcoming of the disease-in-the dish strategy: many patient-specific iPS cell lines don't show any obvious defects related to a disease after conversion into the relevant cell types. Gepstein's team chose long QT syndrome because it stems from genetic mutations that lead to an obvious change

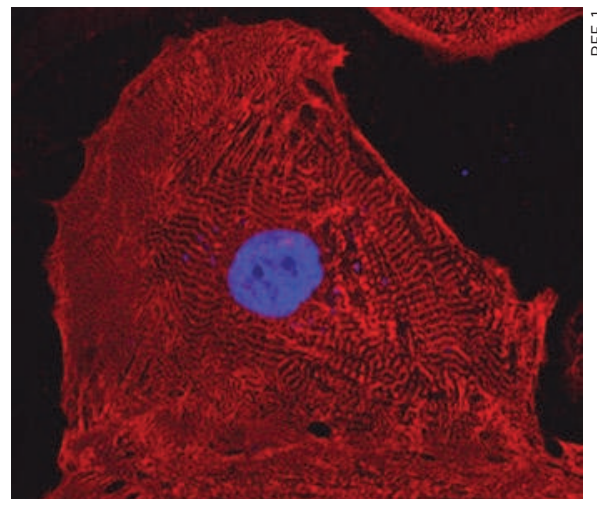

Heart cells derived from induced pluripotent stem cells provide a useful disease model.

in the heart cells. Other conditions successfully modelled from a patient's cells, such as spinal muscular atrophy and Fanconi anaemia, also come with obvious genetic causes and clear physiological readouts. "These are all lowhanging fruits," says Mummery.

Mike Venuti, president of biotech company iPierian in San Francisco, California, says that complex diseases could be modelled if the condition has a distinct effect on cells that is not present in healthy comparisons. For instance, insulin-secretion defects in patient-specific pancreatic $\beta$ cells could be a proxy for diabetes. His firm has made iPS cells from people with Alzheimer's disease, Parkinson's disease and type 2 diabetes and converted them into various cell types for drug screening. He expects that drugs identified using this method will reach clinical trial for conditions such as spinal muscular atrophy in the next few years.

For all the enthusiasm about disease models made from iPS cells, embryonic stem cells (ES cells) shouldn't be forgotten for drug screens, says Stephen Minger, at GE Healthcare in Cardiff, UK. His firm is developing drug-safety tests - including for heart arrhythmias using ES cells. He adds that the genetic manipulations used to make iPS cells could harm them and cloud the search for disease traits. "I think the field has gone a little bit overboard on iPS cells. I think they have tremendous potential, but ES cells do as well." -

\footnotetext{
1. Itzhaki, l. et al. Nature doi: 10.1038/nature09747 (2011).

2. Moretti, A. et al. N. Engl. J. Med. 363, 1397-1409 (2010).

3. Dimos, J. T. et al. Science 321, 1218-1221 (2008).

4. Ebert, A. D. et al. Nature 457, 277-280 (2009).

5. Lee, G. et al. Nature 461, 402-406 (2009).

6. Raya, Á. et al. Nature 460, 53-59 (2009).

7. Marchetto, M. C. N. et al. Cell 143, 527-539 (2010)
}

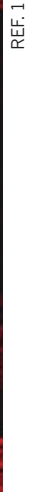

